\title{
Resource use and GHG emissions of eight tropical fruit species cultivated in Colombia
}

Sophie GraefE ${ }^{1,2^{*}}$, Jeimar TAPASCo ${ }^{1}$, Alonso Gonzalez ${ }^{1}$

${ }^{1}$ Int. Cent. Trop. Agric. (CIAT), Recta Cali-Palmira km 17, Cali, Colombia

2 Present address: Georg-August-Univ. Göttingen, Trop. Silvic. For. Ecol., Büsgenweg 1, 37077 Göttingen, Germ., sgraefe@gwdg.de

${ }^{*}$ Correspondence and reprints

Received 16 July 2012 Accepted 11 September 2012

Fruits, 2013, vol. 68, p. 303-314 (C) 2013 Cirad/EDP Sciences All rights reserved DOI: 10.1051/fruits/2013075 www.fruits-journal.org

RESUMEN ESPAÑOL, p. 314

\section{Resource use and GHG emissions of eight tropical fruit species cultivated in Colombia.}

Abstract - Introduction. The cultivation of high-value fruit species is a profitable agricultural activity in many tropical countries; however, intensive fruit cultivation may depend on high amounts of external inputs. The objective of our study was to quantify and compare the resource use during the cultivation of eight tropical fruit species (Rubus glaucus, Solanum quitoense, Passiflora edulis, Cyphomandra betacea, Physalisperuviana, Ananas comosus, Persea americana and Mangifera indica) commonly cultivated in Colombia. It further aimed to identify greenhouse gas (GHG) emissions in the selected production systems and to highlight the potential to contribute to climate change mitigation efforts. Materials and methods. The analysis was based on data from agricultural databases and applied a life-cycle assessment with energy use and GHG emissions as impact categories. Furthermore, economic indicators were taken into account with the aim of integrating the environmental and economic goals of production systems. Results and discussion. Among the eight fruit species studied, mango (Mangifera indica) was found to have the lowest and tree tomato (Cyphomandra betacea) the highest emission profile. The variability in resource use among growers of the same species was high, indicating the need to improve management abilities at the farm level. Mineral fertilizer production was the highest contributor to GHG emissions. GHG- and energy-efficient management alternatives would have a high potential to reduce the carbon footprint of fruit cultivation.

Colombia / fruit crops / tropical fruits / cultivation / greenhouse gases / life-cycle analysis / energy consumption / resource management / sustainable agriculture Utilisation des ressources et émissions de gaz à effet de serre (GES) de huit espèces de fruitiers tropicaux cultivés en Colombie.

Résumé - Introduction. La culture d'espèces fruitières à haute valeur ajoutée est une activité agricole rentable dans de nombreux pays tropicaux, toutefois la culture intensive des arbres fruitiers peut dépendre de grandes quantités d'intrants externes. L'objectif de notre étude a été de quantifier et de comparer l'utilisation des ressources lors de la culture de huit espèces de fruits tropicaux (Rubus glaucus, Solanum quitoense, Passiflora edulis, Cyphomandra betacea, Physalis peruviana, Ananas comosus, Persea americana, Mangifera indica) communément cultivées en Colombie. Elle a également eu pour but d'identifier les gaz à effet de serre (GES) dans les systèmes de production sélectionnés et de mettre en évidence leur contribution aux efforts d'atténuation des changements climatiques. Matériel et méthodes. L'analyse s'est basée sur des données agricoles et elle a porté sur une évaluation du cycle de vie avec l'utilisation d'énergie et les émissions de GES comme catégories d'impact. En outre, des indicateurs économiques ont été pris en compte afin d'intégrer les objectifs environnementaux et économiques des systèmes de production. Résultats et discussion. Parmi les huit espèces fruitières étudiées, le manguier (Mangifera indica) s'est révélé avoir le plus bas profil d'émission et le tamarillo (Cyphomandra betacea) le profil d'émission le plus élevé. La variabilité d'utilisation des ressources entre les producteurs d'une même espèce a été élevée, ce qui indique que les techniques de gestion à l'échelle de l'exploitation pourraient être améliorées. La production des engrais minéraux a été le principal contributeur aux émissions de GES. D'autres méthodes permettant une gestion efficace du GES et de l'énergie auraient un grand intérêt pour réduire l'empreinte carbone de la culture de ces fruitiers.

Colombie / Plante fruitière / fruits tropicaux / pratique culturale / gaz à effet de serre / analyse du cycle de vie / consommation d'énergie / gestion des ressources / agriculture durable 


\section{Introduction}

The cultivation of fruit crops is a profitable agricultural activity in many tropical countries, as most fruit species are high-value crops providing higher net economic benefits than staple crops. In Colombia, where a wide range of climatic conditions allows the cultivation of a diversity of fruit species from sea level up to $2800 \mathrm{~m}$ above sea level, cultivation of fruits plays an important role for the national and export markets [1]. From 2004 to 2008 the area under fruit cultivation increased by 20,000 ha, now comprising an estimated area of 219,626 ha, which is approximately $14 \%$ of agriculturally used land in Colombia [2]. Estimates show that the Colombian fruit sector generates 36\% of incomes obtained through agricultural activities, providing around 121,700 direct jobs [1] and many more indirect ones.

Around the world, market-oriented fruit production systems depend on high amounts of external inputs such as mineral fertilizers and pesticides to sustain yields and to comply with the aesthetic demands of markets; they may therefore have negative environmental impacts despite providing economic benefits. Mineral fertilizers and pesticides have high carbon costs due to energy-intensive production practices [3]. Furthermore, the use of nitrogen fertilizer is responsible for the emission of considerable amounts of $\mathrm{N}_{2} \mathrm{O}$, which has a global warming potential (GWP) of $298 \mathrm{CO}_{2}$ equivalents $[4,5]$. This indicates that production systems receiving high amounts of external inputs may have large carbon footprints.

Without ignoring the role that fruit trees have in carbon sequestration, in the face of the ongoing discussions about climate change it is important to gain knowledge about the resource use in fruit production systems, considering that agricultural activities account for $10-14 \%$ of the total global anthropogenic emissions of greenhouse gas (GHG) [5, 6]. In this context, the product carbon footprint can be seen as a useful tool to describe the total amount of GHG emissions generated by an activity or product and to identify emission hotspots. The calculation of product carbon footprints should include emissions from the entire supply chain, including processes that might occur outside of the business boundary, but are still associated with the product, such as manufacturing processes. These processes are quite diverse and will be unique for each case. To examine the contribution of each agricultural activity to the global warming potential of land-use systems would allow identifying the most effective mitigation actions such as alternative management practices that manage carbon and nitrogen flows more efficiently $[7,8]$. The aim of our present study was to quantify the resource use of eight tropical fruit species commonly cultivated in Colombia and other tropical countries, and to determine their global warming potential (carbon footprint) and energy use per unit of product and area under cultivation by means of a life-cycle assessment.

\section{Materials and methods}

For our study, eight economically important fruit species in Colombia were selected: Andean blackberry (Rubus glaucus), lulo (Solanum quitoense), passion fruit (Passiflora edulis), tree tomato (Cyphomandra betacea), golden berry (Physalis peruviana), pineapple (Ananas comosus), avocado (Persea americana) and mango (Mangifera indica). Seven out of the eight fruit species are currently cultivated on more than 5,000 ha; mango and avocado are even cultivated on more than 15,000 ha. The only species with a small cultivation area is golden berry, with less than 1,000 ha under cultivation. By far the highest yields are encountered in pineapple plantations (table I).

A life-cycle approach [9-11] was applied to estimate the resource use of the fruit production systems. Energy use and GHG emissions were chosen as impact categories. A "cradle-to-farm-gate" approach was taken as the system boundary, which includes the production of all input goods to the farming system and all outflow emissions from the system. Thus, the farm gate was defined as the geographic border [11]. Two functional units were selected, which were 1 ha and $1 \mathrm{t}$ of fruits (gross weight). The analysis conducted was only based on existing cultivation 
Table I.

Production characteristics of eight fruit species cultivated in Colombia.

\begin{tabular}{|c|c|c|c|c|c|c|}
\hline Common name & Scientific name & $\begin{array}{l}\text { Area under cultivation } \\
\text { (ha) }\end{array}$ & $\begin{array}{c}\text { Yield } \\
\left(\mathrm{kg} \cdot \mathrm{ha}^{-1}\right)[2]\end{array}$ & $\begin{array}{c}\text { Energy value } \\
\left(\mathrm{kJ} \cdot 100 \mathrm{~g}^{-1} \text { edible portion }\right)^{1}\end{array}$ & $\begin{array}{l}\text { Economic life } \\
\text { (years) }\end{array}$ & $\begin{array}{l}\text { Altitudinal range } \\
\qquad(\mathrm{m} \text { asl) }\end{array}$ \\
\hline $\begin{array}{l}\text { Andean } \\
\text { blackberry }\end{array}$ & Rubus glaucus & 10,743 & 8,666 & 121 & 4 & $1800-2400$ \\
\hline Lulo & Solanum quitoense & 5,631 & 8,250 & 155 & 2 & $1000-2500$ \\
\hline Passion fruit & Passiflora edulis & 6,372 & 17,182 & 251 & $1.5-2$ & $900-2000$ \\
\hline Tree tomato & $\begin{array}{l}\text { Cyphomandra } \\
\text { betacea }\end{array}$ & 6,446 & 16,616 & 126 & $3-10$ & $1500-3000$ \\
\hline Golden berry & Physalis peruviana & 841 & 18,386 & 251 & $1-2$ & $1800-2800$ \\
\hline Pineapple & Ananas comosus & 10,163 & 38,153 & 238 & 2 & $300-1500$ \\
\hline Avocado & Persea americana & 15,496 & 9,429 & 607 & 25 & $0-2500$ \\
\hline Mango & Mangifera indica & 17,764 & 10,160 & 247 & 30 & $0-1200$ \\
\hline
\end{tabular}

practices; the pre-clearing of land was not considered, as this was difficult to measure. Furthermore, it was assumed that fruits were cultivated in monocultures. Input parameters that were taken into account for this study were mineral fertilizers, organic fertilizers, soil amendments (lime), pesticides and labor. Data on quantity of inputs and yields were taken from statistical databases ${ }^{1}$ [2]. Inputs were converted to energy values and GHG emissions using default values published in the literature (table II). GHG emissions refer to (1) embodied emissions $\left(\mathrm{CO}_{2}\right)$ originating from the production of agricultural inputs, and (2) direct field emissions $\left(\mathrm{N}_{2} \mathrm{O}\right)$ from mineral and organic fertilizer application, which were converted to $\mathrm{CO}_{2}$ equivalents. Estimates of embodied carbon emissions (manufacturing of agricultural products) were based on values published by Lal [3]. Nitrous oxide $\left(\mathrm{N}_{2} \mathrm{O}\right)$ emissions were estimated based on the methodology proposed by Brentrup et al. [4]: $\left[\mathrm{N}_{2} \mathrm{O}\right.$ emissions $\left(\mathrm{kg} \mathrm{N}\right.$ O-N $\left.\cdot \mathrm{ha}^{-1}\right)=0.0125 \times$ $\mathrm{N}$ application $\left.\left(\mathrm{kg} \cdot \mathrm{ha}^{-1}\right)\right]$.

The applied $\mathrm{N}$ rate was corrected for $\mathrm{NH}_{3}$ emissions (which predominantly occur

\footnotetext{
${ }^{1}$ MADR, Agronet (Stat. database Colomb. Minist. Agric.), available at: http://www agronet.gov.co/agronetweb/AnalisisEstadisticas/tabid/73/Default.aspx (access. 26 Sept. 2011).
}

earlier than the $\mathrm{N}_{2} \mathrm{O}$ emissions) as suggested by Brentrup et al. [4].

Economic indicators (i.e., production costs, net income, labor) were analyzed with the aim of integrating the environmental and economic goals of production systems. We decided to separate two economic indicators when looking at medium/large and small fruit growers, respectively. As the most convenient economic indicator, for medium and large growers we chose "benefit/cost ratio", whereas small growers were better characterized through the indicator "net income per labor hour".

\section{Results}

\subsection{Farm inputs}

Mineral fertilizers (N-P-K) were applied at rates of $0.2-2.7 \mathrm{t} \cdot \mathrm{ha}^{-1}$.year ${ }^{-1}$, but considerable differences among species were observed (table III). Mango was found to be the least fertilizer-intensive production system, whereas tree tomato and golden berry received mineral fertilizer inputs that were about 15 times higher. Tree tomato and golden berry also received considerable amounts of organic fertilizers and soil amendments. Both species have high yield levels (table I), indicating that high amounts of nutrients are removed at harvest. In 


\section{Table II.}

Default values for calculating energy use and $\mathrm{CO}_{2}$ equivalent emission of agricultural inputs.

a) Energy use of agricultural inputs

\begin{tabular}{|c|c|c|c|c|c|c|c|c|c|}
\hline Parameter & $\mathrm{N}$ fertilizer & $\begin{array}{l}\text { P fertilizer } \\
\left(\mathrm{MJ} \mathrm{kg}^{-1}\right)\end{array}$ & $\mathrm{K}$ fertilizer & Fungicide & 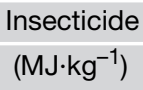 & Herbicide & 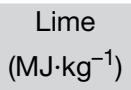 & $\begin{array}{l}\text { Organic fertilizer } \\
\qquad\left(\mathrm{MJ}^{\prime} \cdot \mathrm{kg}^{-1}\right)\end{array}$ & $\begin{array}{c}\text { Labor } \\
\left(\text { MJ.day labor }^{-1}\right)\end{array}$ \\
\hline Quantity & 78.23 & 17.5 & 13.8 & 91.7 & 199.4 & 237.8 & 1.3 & 0.38 & 8 \\
\hline Reference & [30] & [30] & [30] & [31] & [31] & [31] & [32] & [31] & [31] \\
\hline
\end{tabular}

b) Carbon equivalent emission

\begin{tabular}{|c|c|c|c|c|c|c|c|c|c|c|}
\hline Parameter & Nitrogen & Phosphorus & Potassium & Lime & Manure & Herbicides $^{1}$ & Insecticides ${ }^{1}$ & Fungicides ${ }^{1}$ & $\begin{array}{c}\mathrm{N}_{2} \mathrm{O} \\
\text { emissions } \\
\left(\mathrm{kg} \cdot \mathrm{ha}^{-1}\right)\end{array}$ & $\begin{array}{c}\text { Global warming } \\
\text { potential } \\
\left(\mathrm{CO}_{2} \mathrm{Eq}\right) \text { of } \mathrm{N}_{2} \mathrm{O} \\
(\mathrm{kq})\end{array}$ \\
\hline Quantity & 1.3 & 0.2 & 0.15 & 0.16 & 0.008 & 6.3 & 5.1 & 3.9 & $\begin{array}{c}\mathrm{N}\left(\mathrm{kg} \mathrm{ha}^{-1}\right) \times \\
0.0125\end{array}$ & 298 \\
\hline Reference & [3] & [3] & [3] & [3] & [3] & [3] & [3] & [3] & [33] & [5] \\
\hline
\end{tabular}

\section{Table III.}

Inputs for eight fruit production systems in Colombia (numbers in parentheses are standard error) ${ }^{1}$.

\begin{tabular}{|c|c|c|c|c|c|c|c|}
\hline \multirow[t]{2}{*}{ Fruits studied } & Mineral fertilizers & Organic fertilizers & Soil amendments & Fungicides & Insecticides & Herbicides & \multirow{2}{*}{$\begin{array}{c}\text { Labor } \\
\left(\text { hours }^{\prime} \mathrm{ha}^{-1}\right)\end{array}$} \\
\hline & \multicolumn{3}{|c|}{$\left(\mathrm{kg} \cdot \mathrm{ha}^{-1}\right)$} & & $\left(\mathrm{L} \cdot \mathrm{ha}^{-1}\right)$ & & \\
\hline Andean blackberry & $739(177)$ & 2051(906) & $0(0)$ & $14.0(1.6)$ & $6.0(1.5)$ & $1.1(0.5)$ & $1095(70)$ \\
\hline Avocado & $756(254)$ & $560(182)$ & $127(79)$ & $11.1(4.9)$ & $8.2(3.6)$ & $0.4(0.2)$ & $1047(294)$ \\
\hline Golden berry & 2249 (1069) & 1568 (1019) & $989(410)$ & $11.4(0.9)$ & $5.9(2.3)$ & $1.0(0.9)$ & 3915 (276) \\
\hline Lulo & $1533(778)$ & $85(43)$ & $323(142)$ & 15.9 (3.6) & $11.7(1.6)$ & $4.3(1.4)$ & $1214(109)$ \\
\hline Mango & $158(30)$ & $337(226)$ & $96(42)$ & $3.8(1.9)$ & $7.5(3.5)$ & $0.7(0.4)$ & $530(72)$ \\
\hline Passion fruit & $828(63)$ & $70(52)$ & $47(12)$ & $20.8(2.8)$ & $14.3(2.4)$ & $5.8(1.9)$ & $1364(88)$ \\
\hline Pineapple & $982(41)$ & $41(40)$ & 234 (123) & $2.2(0.2)$ & $23.8(2.3)$ & $12.7(4.3)$ & $1198(67)$ \\
\hline Tree tomato & 2667 (836) & 2831 (997) & $1108(471)$ & $28.6(4.4)$ & $15.1(2.2)$ & $3.5(0.9)$ & 1400 (120) \\
\hline
\end{tabular}

${ }_{1}^{1}$ MADR, Agronet (Stat. database Colomb. Minist. Agric.), available at: http://www.agronet.gov.co/agronetweb/AnalisisEstadisticas/ tabid/73/Default.aspx (access. 26 Sept. 2011).

general, the amount of organic fertilizers applied in Colombian fruit production systems was found to be low compared with mineral fertilizers. The highest share of pesticide inputs was found in tree tomato, passion fruit and pineapple production systems (table III). Fungicides were the most widely applied pesticide, followed by insecticides and herbicides. However, these values could vary greatly based on where the crops are established, as adverse environmental conditions result in more frequent applications. Only in pineapple production systems were insecticides and herbicides applied at higher rates than fungicides. When converting pesticide inputs on a yield basis (per ton of product harvested), lulo was found to be the most pesticide-intensive fruit (data not shown). The most laborintensive fruit species was golden berry, which required labor input of 3,915 working hours $\cdot$ ha $^{-1} \cdot$ year $^{-1}$, whereas mango was 


\section{Table IV.}

Energy inputs and outputs, the output / input ratio and energy productivity of eight fruit production systems in Colombia (numbers in parentheses are the percentage share).

\begin{tabular}{|c|c|c|c|c|c|c|c|c|c|}
\hline \multirow[t]{2}{*}{$\begin{array}{l}\text { Fruits } \\
\text { studied }\end{array}$} & $\begin{array}{l}\text { Mineral } \\
\text { fertilizers }\end{array}$ & Pesticides & $\begin{array}{c}\text { Soil } \\
\text { amendments }\end{array}$ & $\begin{array}{l}\text { Organic } \\
\text { fertilizers }\end{array}$ & Labor & $\begin{array}{l}\text { Total energy } \\
\text { input }\end{array}$ & \multirow[t]{2}{*}{$\begin{array}{l}\text { Output } \\
\text { energy }\end{array}$} & \multirow{2}{*}{$\begin{array}{l}\text { Output / } \\
\text { Input } \\
\text { ratio }\end{array}$} & \multirow{2}{*}{$\begin{array}{c}\text { Energy } \\
\text { productivity } \\
\left(\mathrm{t} \cdot \mathrm{GJ}^{-1}\right)\end{array}$} \\
\hline & & & & $\left(G J \cdot h a^{-1}\right)$ & & & & & \\
\hline $\begin{array}{l}\text { Andean } \\
\text { blackberry }\end{array}$ & $13.4(74.0)$ & $2.7(14.9)$ & $0(0)$ & $0.8(4.4)$ & $1.1(6.1)$ & 18.1 & 7.7 & 0.5 & 0.4 \\
\hline Avocado & $13.8(77.1)$ & $2.8(15.6)$ & $0.2(1.1)$ & $0.2(1.1)$ & $1.1(6.1)$ & 17.9 & 46.7 & 2.6 & 0.8 \\
\hline Golden berry & $40.9(83.1)$ & $2.5(5.1)$ & $1.3(2.6)$ & $0.6(1.2)$ & 3.9 (7.9) & 49.2 & 59.1 & 1.2 & 0.9 \\
\hline Lulo & 27.9 (81.1) & $4.8(14.0)$ & $0.4(1.2)$ & $0.0(0)$ & $1.2(3.5)$ & 34.4 & 13.7 & 0.5 & 0.4 \\
\hline Mango & $2.9(50.9)$ & $2.0(35.1)$ & $0.2(3.5)$ & $0.1(1.8)$ & $0.5(8.8)$ & 5.7 & 17.3 & 3.5 & 2.0 \\
\hline Passion fruit & $15.1(66.5)$ & $6.1(26.9)$ & $0.1(0.4)$ & $0.0(0)$ & $1.4(6.2)$ & 22.7 & 38.6 & 1.7 & 0.8 \\
\hline Pineapple & $17.9(65.3)$ & $7.9(28.8)$ & $0.3(1.1)$ & $0.0(0)$ & $1.2(4.4)$ & 27.4 & 55.8 & 2.1 & 1.7 \\
\hline Tree tomato & 48.6 (82.4) & $6.5(11.0)$ & $1.4(2.4)$ & $1.1(1.9)$ & $1.4(2.4)$ & 59.0 & 24.6 & 0.4 & 0.4 \\
\hline
\end{tabular}

the least labor-intensive fruit, with 530 working hours $\cdot$ ha $^{-1} \cdot$ year $^{-1}$ (table III).

\subsection{Energy}

Mineral fertilizers represented by far the highest energy-intensive input into fruit production systems $(51-83 \%$ of total energy input), followed by pesticides (5-35\% of total energy input). The contribution of organic fertilizers, soil amendments and human labor to total energy input was less than $10 \%$ (table IV). The most energy-intensive production system was found to be tree tomato, followed by golden berry and lulo, whereas the least energy-intensive production system was mango (table $I V$ ).

The highest output energy (i.e., yield converted to an energetic value) was provided by golden berry, pineapple and avocado. In the case of golden berry and pineapple, the high energy yield is mainly due to the high yield levels of the fruits [(25 and 38) th ha ${ }^{-1}$. year $^{-1}$, respectively]. Avocado has lower yields but a much higher energy value compared with other fruits due to its oil content (tables I, IV).

The highest energy output/input ratios were obtained for avocado and mango, followed by pineapple, golden berry and passion fruit. Negative energy balances were calculated for Andean blackberry, lulo and tree tomato, which indicates that the energy input into those production systems is higher than the energy output provided by yields. The highest energy productivity (i.e., yield divided by energy input) was obtained for mango and pineapple, whereas the lowest energy productivity was calculated for Andean blackberry, lulo and tree tomato (table IV).

\subsection{GHG emissions}

For GHG emissions of the eight fruit production systems, the highest emissions on a hectare basis were obtained for tree tomato and golden berry, whereas the lowest emissions were found for mango, avocado and Andean blackberry (figure 1A). A different picture emerged when $\mathrm{CO}_{2}$ equivalent emissions were converted to $1 \mathrm{t}$ of harvested product (figure $1 B$ ). In this case, the lowest emissions were calculated for mango, pineapple and passion fruit, whereas the highest emissions were obtained for lulo and tree tomato. The highest share of GHG emissions in the analyzed production systems was made up of embodied $\mathrm{CO}_{2}$ emissions from fertilizer production; the second highest 
Figure 1.

Sources of direct and embodied GHG emissions per hectare $(A)$ and yield $(B)$ in eight fruit production systems in Colombia.

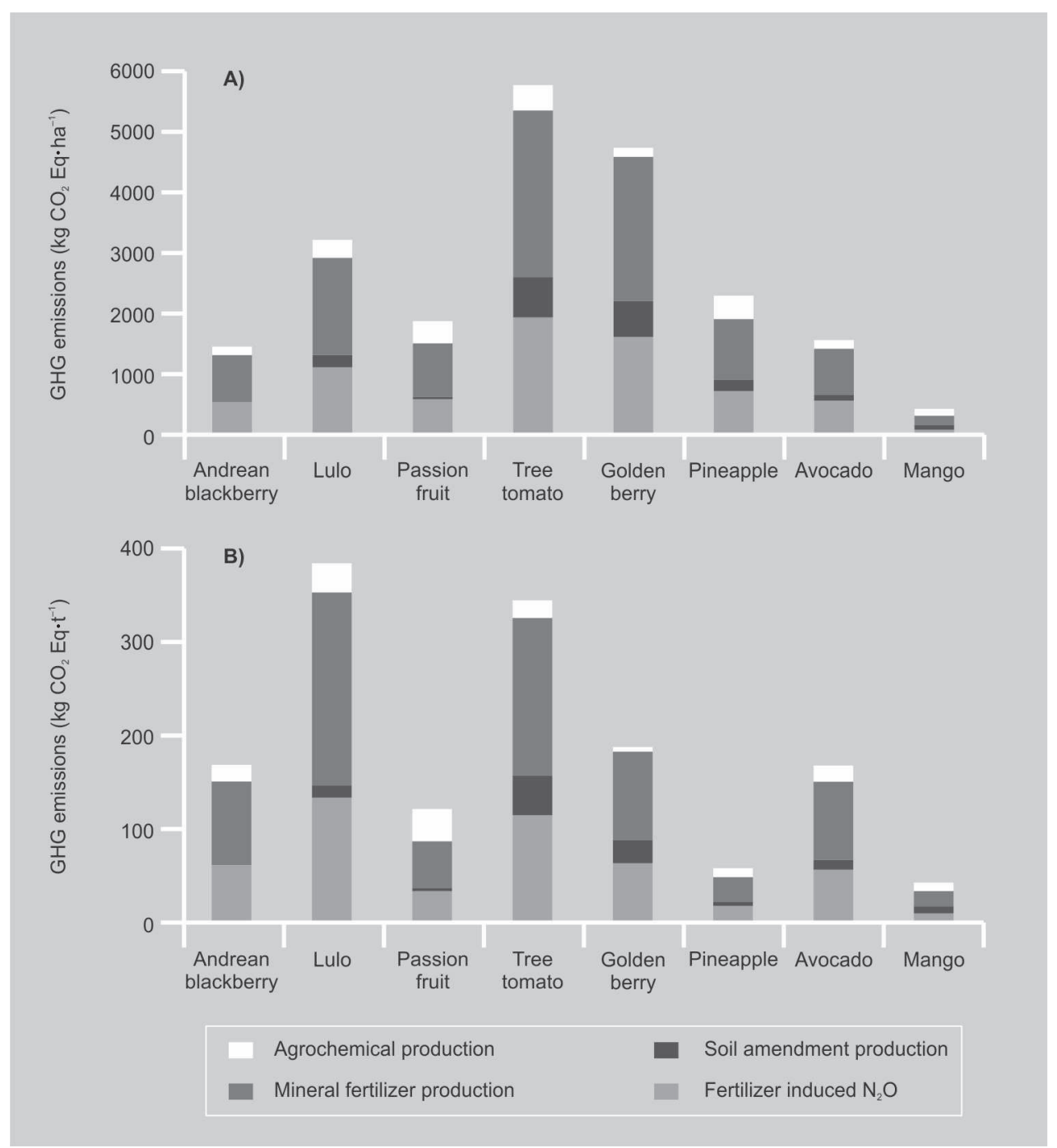

contributor was $\mathrm{N}_{2} \mathrm{O}$ emissions from mineral fertilizer application. Together they contributed between $61-85 \%$ of total $\mathrm{CO}_{2}$ equivalent GHG emissions.

Taking into account the whole area that is cultivated with the eight fruit species selected for this study in Colombia (about $73,450 \mathrm{ha}$ ), total emissions amounted to $141,514 \mathrm{t} \mathrm{CO}_{2} \mathrm{Eq} \mathrm{year}^{-1}$. The highest contributor to absolute emissions was tree tomato; the lowest was golden berry (table $\mathrm{V}$ ).

\subsection{Economic indicators}

Pineapple cultivation yielded the highest benefit / cost ratio among the medium and large growers, closely followed by avocado. The lowest benefit / cost ratios were obtained for Andean blackberry, mango and lulo. When looking at the net income per labor hour of small fruit growers, again pineapple and avocado obtained the highest scores, whereas the lowest net incomes per labor hour were calculated for Andean blackberry, lulo and passion fruit (table VI). Net income per GHG emission was taken as a means of combining an economic with an environmental indicator. Golden berry and avocado showed a relatively high net income per emission ( $>4.50 \mathrm{US} \$ \cdot \mathrm{CO}_{2} \mathrm{Eq}^{-1}$ ), whereas the net income per emission for Andean blackberry, lulo and tree tomato was below 2.00 US\$. $\mathrm{CO}_{2} \mathrm{Eq}^{-1}$ (table VI). 


\begin{tabular}{|c|c|c|}
\hline $\begin{array}{l}\text { Fruits } \\
\text { studied }\end{array}$ & $\begin{array}{l}\text { Area under cultivation } \\
\text { (ha) [2] }\end{array}$ & $\begin{array}{l}\text { Total GHG emissions } \\
\left(\mathrm{t} \mathrm{CO}_{2} \text { Eq} \cdot y e a r^{-1}\right)\end{array}$ \\
\hline Andean blackberry & 10,743 & 15,829 \\
\hline Avocado & 15,496 & 24,324 \\
\hline Golden berry & 841 & 3,952 \\
\hline Lulo & 5,631 & 17,849 \\
\hline Mango & 17,764 & 7,830 \\
\hline Passion fruit & 6,372 & 11,721 \\
\hline Pineapple & 10,163 & 22,953 \\
\hline Tree tomato & 6,446 & 37,056 \\
\hline
\end{tabular}

\section{Table VI.}

Economic characteristics of eight fruit production systems in Colombia (numbers in parentheses are standard error).

\begin{tabular}{|c|c|c|c|c|c|}
\hline \multirow{2}{*}{$\begin{array}{l}\text { Fruits } \\
\text { studied }\end{array}$} & Total costs ${ }^{1}$ & Net income ${ }^{1}$ & \multirow{2}{*}{$\begin{array}{c}\text { Benefit / cost } \\
\text { ratio }^{2}\end{array}$} & \multirow{2}{*}{$\begin{array}{l}\text { Net income per labor hour }{ }^{3} \\
\text { (US\$) }\end{array}$} & \multirow{2}{*}{$\begin{array}{l}\text { Net income per emission } \\
\quad\left(\mathrm{US} \$ \cdot \mathrm{CO}_{2} \mathrm{Eq}^{-1}\right)\end{array}$} \\
\hline & \multicolumn{2}{|c|}{$\left(\right.$ US\$·ha $\left.{ }^{-1}\right)$} & & & \\
\hline Andean blackberry & $3,868(335)$ & $1,434(255)$ & $1.37(0.04)$ & $2.50(0.14)$ & $0.93(0.14)$ \\
\hline Avocado & $3,168(409)$ & $6,102(864)$ & 2.93. $(0.12)$ & $7.76(0.74)$ & $4.78(0.81)$ \\
\hline Golden berry & $9,751(413)$ & $11,364(7,165)$ & $2.16(0.69)$ & $3.94(1.54)$ & $5.84(4.75)$ \\
\hline Lulo & $4,470(906)$ & 257 (439) & $1.05(0.17)$ & $2.96(0.91)$ & $1.47(0.75)$ \\
\hline Mango & $2,186(587)$ & $1,245(488)$ & $1.56(0.13)$ & $4.20(0.00)$ & $2.63(0.77)$ \\
\hline Passion fruit & 4,808 (296) & $5,704(1,165)$ & $2.18(0.27)$ & $2.73(0.00)$ & $3.14(0.64)$ \\
\hline Pineapple & $3,592(91)$ & $7,585(465)$ & $3.11(0.06)$ & $6.59(0.00)$ & $3.38(0.21)$ \\
\hline Tree tomato & $6,217(1,054)$ & $6,598(1,961)$ & $2.06(0.10)$ & $4.51(0.73)$ & $1.63(0.79)$ \\
\hline
\end{tabular}

\section{Discussion}

\subsection{Resource use}

Our study revealed the existence of considerable energy and carbon costs in tropical fruit production systems. This is mainly attributable to the high amount of external inputs applied, such as mineral fertilizers and agrochemicals, which are linked to carbonand energy-intensive production processes [3]. However, we found a high variability among species. Perennials (i.e., mango, avocado) scored better than annuals and semiannuals (i.e., tree tomato, lulo). The only exception was pineapple, which despite being a semi-annual, showed low emission figures, especially on a yield basis. The smallest energy and carbon footprint both on a hectare and yield basis was calculated for mango, whereas the largest footprint was obtained for tree tomato on a hectare basis, and for lulo on a yield basis.

One main challenge of feeding the world without increasing the carbon footprint of farming systems is to produce more with fewer inputs, which requires the improvement of current technologies [12]. In this context, it is important to identify farmers' decisive factors for successful farm 
management that combine high yields with low consumption of fertilizers and pesticides. In perennial tropical tree species such as mango and avocado, yield is also significantly related to flowering, which in turn is controlled by environmental factors. In species such as lulo, golden berry and Andean blackberry, on the other hand, flowering is less erratic. Furthermore, it must be considered that fruit species native to the Andean region (i.e., Andean blackberry, lulo, tree tomato, golden berry) are still less domesticated than species grown worldwide such as pineapple or mango, indicating the need to invest more in breeding programs for the identification of high-yielding varieties.

A high variability of farm inputs among fruit growers was also confirmed by Coltro et al., who analyzed the environmental profile of 30 orange growers in Brazil by means of a detailed production inventory [13]. They observed a high variation of input levels ranging from 120-4,400 MJ energy, 0.3$65 \mathrm{~kg}$ fertilizer (NPK), $0.1-13.5 \mathrm{~kg}$ pesticides and 8-650 kg soil correctors for the production of $1 \mathrm{t}$ of oranges. Only $21 \%$ of the orange growers showed a good environmental performance, which they defined as a consumption of inputs equal to or lower than the weighted average. Coltro et al. conducted a similar study on the environmental profile of Brazilian green coffee, and found that $1 \mathrm{t}$ of green coffee required approximately $0.9 \mathrm{t}$ fertilizer, $0.62 \mathrm{t}$ soil amendments (limestone) and $10 \mathrm{~kg}$ of pesticides [14]. When the amounts of fertilizer and pesticides applied were presented as a function of productivity, it did not show a direct correlation. A similar tendency was also observed by Mouron et al., who conducted a life-cycle analysis to examine the relationship between environmental and income indicators of integrated apple producers in Switzerland [15]. They did not identify a trade-off between income and environmental impact, and found that the management competence of the farm manager was the most important success criterion for sustainable orchard farming. Similar studies need to be conducted among producers of tropical fruits to identify best-bet management practices, as a surrogate for the lack of extension services that prevail in countries involved in tropical fruit production. Many of the species considered in this study have been "domesticated" by farmers with little input from research programs. More efforts should be undertaken to improve efficiency in the production systems by identifying more productive varieties that make better use of provided inputs.

\subsection{Energy}

Regarding energy consumption, no comparable studies were available for fruit production systems; however, similar assessments were made of vegetables and cotton. Bojacá and Schrevens analyzed the energy consumption of peri-urban horticulture (coriander, lettuce, radish, spinach) in Bogotá by means of an input-output energy assessment, and found energy consumption figures between (6.6 and 18.8) $\mathrm{GJ} \cdot \mathrm{ha}^{-1}$ [16], which are within the lower range of the results from our study (i.e., mango and avocado). However, the energy balances were negative for all except spinach. Much higher energy consumption in vegetable production was observed by Ozkan et al., who conducted an energy analysis of greenhouse vegetable production in Turkey [17]. They found energy consumption of (135 and 127) $\mathrm{GJ} \cdot \mathrm{ha}^{-1}$ for cucumber and tomato, respectively, but the output / input ratio for tomato was still positive (1.26), mainly due to the high yield level of tomato cultivated in greenhouses. According to Yilmaz et al., cotton production in Turkey consumed a total of $49.73 \mathrm{GJ} \cdot \mathrm{ha}^{-1}$ [18]. As this is a highly mechanized production system, diesel energy consumption made up the highest share, followed by fertilizer and machinery energy. The [output energy / input energy] ratio was 0.74 , and energy productivity was $0.06 \mathrm{~kg}$ cotton $\cdot \mathrm{MJ}^{-1}$.

\subsection{GHG emissions}

Several studies were conducted on GHG emissions in sugarcane production systems $[10,19,20]$. Around half of the global warming potential of sugarcane was related to direct and indirect fossil-energy use; the reminder was due to field emissions [20]. 
Plassmann et al. calculated emissions of 26-210 $\mathrm{kg} \mathrm{CO}_{2} \cdot \mathrm{t}^{-1}$ for sugarcane production in Zambia and Mauritius [19]. They highlighted that the methodology chosen may strongly affect carbon footprints. This is also the case for the present study, which has its limitations since the input parameters that were taken into account only refer to the farm inputs and its related emissions, whereas land-use change, $\mathrm{C}$ sequestration and co-products originating from production were excluded.

Despite emitting GHGs, especially treebased land-use systems can also be sinks of $\mathrm{C}$, whereas annuals and semi-perennials only temporally store $C$ [21, 22]. In our case study, especially mango and avocado production systems are interesting in terms of biomass carbon storage, as they have an economic life of more than 20 years. The amount of carbon storage increases with tree biomass until trees reach maturity, at which point carbon storage reaches a steady state. In fruit production, however, a constant renewal of the canopy takes place after trees are pruned, which makes the dynamics of carbon balances more complex. Andean blackberry could also be considered as a perennial species, but its biomass accumulation is non-significant when compared with tree species. Furthermore, trees also have a different impact on soil properties than annual crops, which is due to their longer residence time, allowing a larger biomass accumulation and a continuous and more extensive root system [23, 24]. However, it is most likely that perennial fruit plantations will store less $\mathrm{C}$ than native forest cover [25].

Carbon stocks of vegetation being present before establishing fruit plantations should also be taken into account in C footprint estimations. This has been excluded from the present study, since information about the original vegetation was not available. It may become highly relevant in the case of nonperennial fruit crops expanding rapidly into new areas. Land-use change usually constitutes by far the greatest emission source among input parameters, as was the case for sugarcane, reported by Plassmann et al. [19]. When forest land is converted to cropland, emissions from land-use change are likely to be very high compared with direct and embodied emissions from farm inputs, and may dominate the emission profile. This would override any efforts to change the farm management to reduce carbon footprints, as those measures would have only a small proportional effect [19].

Despite larger C footprints, annual and semi-perennial crops have the advantage that they offer more flexibility in economic terms than perennials, which might be regarded as a trade-off to the aim of producing fruit species with a low emission profile. Especially golden berry, Andean blackberry and lulo keep market prices quite stable throughout the year, yield fruits on a weekly basis and initiate production about 6 months to 8 months after being planted. Mango, passion fruit and avocado, on the other hand, tend to be very seasonal, and the market gets flooded during the main harvest periods.

\subsection{Outlook}

A drawback of comparing carbon footprints of different products and countries is the uncertainty originating from different data sources, and use of differing emission factors, system boundaries, and treatment of land-use change, which should be explicitly noted in each case [26]. Extensive farming systems usually have lower yields and emissions per hectare, but greater emissions per $\mathrm{kg}$ of product compared with more intensive systems [11], which makes it important to present results both on a hectare and a yield basis, as we did in our study. However, per area benchmarking of GHG emissions is considered the most appropriate way for comparing the resource efficiency of farming systems [27, 28].

There is a need to identify carbon-efficient management alternatives, e.g., replacing pesticides through integrated pest control and mineral fertilizers through organic fertilizers and complementary cover crops that fix nitrogen [27, 29]. In this respect, life-cycle analysis and the concept of footprinting can be regarded as an important tool to establish a basis for the sustainability of products and to understand potential environmental 
impacts. It is the first step for quantifying the contribution of an activity or product to climate change and to identify areas where GHG emissions can be effectively reduced Energy use and GHG emissions are closely linked and, to avoid emissions in the agricultural sector, the energy efficiency in many production systems needs to be improved. The potential to reduce emissions and to increase carbon sinks in fruit production systems is high, and may contribute significantly to climate change mitigation efforts. As a next step, we recommend conducting more site-specific case studies that also take into account the dynamics of farmers' decision-making on how to manage their farms.

\section{References}

[1] Tafur R., Propuesta frutícola para Colombia y su impacto en la actividad económica nacional, regional y departamental, in: Fisher G., Miranda D., Piedrahíta W., Magnitskiy S. (Eds.), Congr. Colomb. Hortic., Soc. Colomb. Cienc. Hortíc. (SCCH), Mem., Bogotá, Colombia, 2006, pp. 47-66.

[2] Anon., Anuario estadístico de frutas y hortalizas 2004-2008, Minist. Agric. Desarro. Rural (MADR), Bogota, Colombia, 2009.

[3] Lal R., Carbon emissions from farm operations, Environ. Int. 30 (2004) 981-990.

[4] Brentrup F., Küsters J., Lammel J., Kuhlmann $\mathrm{H}$., Methods to estimate on-field nitrogen emissions from crop production as an input to LCA studies in the agricultural sector, Int. J. Life Cycle Assess. 5 (2000) 349-357.

[5] Anon., Climate change 2007: The physical science basis, Contrib. Work. Group I 4th Assess. Rep. Intergov. Panel Clim. Chang. (IPCC), Camb. Univ. Press, Camb., U.K., 2007.

[6] Smith P., Martino D., Cai Z., Gwary D., Janzen H., Kumar P., McCarl B., Ogle S., O'Mara F., Rice C., Scholes B., Sirotenko O., Howden M., McAllisterT., Pan G., Romanenkov V., Schneider U., Towprayoon S., Policy and technological constraints to implementation of greenhouse gas mitigation options in agriculture, Agr. Ecosyst. Environ. 118 (2007) 6-28.
[7] Anon., FAO profile for climate change, Food Agric. Organ. U. N. (FAO), Rome, Italy, 2009.

[8] Glantz M.H., Gommes R, Ramasamy S., Coping with a changing climate: considerations for adaptation and mitigation in agriculture, FAO, Environ. Natural Res. Manag. Ser. 15, Rome, Italy, 2009.

[9] Mrini M., Senhaji F., Pimentel D., Energy analysis of sugar beet production under traditional and intensive farming systems and impacts on sustainable agriculture in Morocco, J. Sustain. Agric. 20 (2002) 5-28.

[10] Ramjeawon T., Life cycle assessment of cane-sugar on the island of Mauritius, Int. J. Life Cycle Assess. 9 (2004) 254-260.

[11] Harris S., Narayanaswamy V., A literature review of life cycle assessment in agriculture, Aust. Gov., Rural Ind. Res. Dev. Corp. (RIRDC), RIRDC Publ. No 09/029, Canberra, Aust., 2009.

[12] Clay J., Freeze the footprint of food, Nature 475 (2011) 287-289.

[13] Coltro L., Mourad A.L., Kletecke R.M., Mendonça T.A., Germer S.P.M., Assessing the environmental profile of orange production in Brazil, Int. J. Life Cycle Assess. 14 (2009) 656-664.

[14] Coltro L., Mourad A.L., Oliveira P., Baddini J.P., Kletecke R.M., Environmental profile of Brazilian green coffee, Int. J. Life Cycle Assess. 11 (2006) 16-21.

[15] Mouron P., Scholz R.W., Nemecek T., Weber O., Life cycle management on Swiss fruit farms: Relating environmental and income indicators for apple-growing, Ecol. Econ. 58 (2006) 561-578.

[16] Bojacá, C.R., Schrevens, E., Energy assessment of peri-urban horticulture and its uncertainty: Case study for Bogota, Colombia, Energy 35 (2010) 2109-2119.

[17] Ozkan B., Kurklu A., Akcaoz H., An input-output analysis in greenhouse vegetable production: a case study for Antalya region of Turkey, Biomass Bioenerg. 26 (2004) 89-95.

[18] Yilmaz I., Akcaoz H., Ozkan B., An analysis of energy use and input costs for cotton production in Turkey, Renew. Energ. 30 (2004) 145-155.

[19] Plassmann K., Norton A., Attarzadeh N., Jensen M.P., Brenton P., Edwards-Jones G., Methodological complexities of product carbon footprinting: a sensitivity analysis of key variables in a developing country context, Environ. Sci. Technol. 13 (2010) 393-404. 
[20] Renouf M.A., Wegener M.K., Pagan R.J., Life cycle assessment of Australian sugarcane production with a focus on sugarcane growing, Int. J. Life Cycle Assess. 15 (2010) 927-937.

[21] Montagnini F., Nair P.K.R., Carbon sequestration: An underexploited environmental benefit of agroforestry systems, Agroforest. Syst. 61 (2004) 281-295.

[22] Shively G.E., Zelek C.A., Midmore D.J., Nissen T.M., Carbon sequestration in a tropical landscape, Agrofor. Syst. 60 (2004) 189-197.

[23] Sanchez P.A., Buresh R.J., Leakey R.R.B., Trees, soils, and food security, Philos. Trans. R. Soc. Lond., Ser. B. 353 (1997) 949-961.

[24] Albrecht A., Kandji S.T., Carbon sequestration in tropical agroforestry systems, Agric. Ecosyst. Environ. 99 (2003) 15-27.

[25] Ordóñez J.A.B., de Jong B.H.J., GarcíaOliva F., Aviña F.L., Pérez J.V., Guerrero G., Martínez R., Masera O., Carbon content in vegetation, litter, and soil under 10 different land-use and land-cover classes in the Central Highlands of Michoacan, Mexico, For. Ecol. Manag. 255 (2008) 2074-2084.

[26] Brenton P., Edwards-Jones G., Jensen M.F., Carbon labeling and low-income country exports: A review of the development issues, Dev. Policy Rev. 27 (2009) 243-267.
[27] Niggli U., Fließbach A., Hepperly P., Scialabba N., Low greenhouse gas agriculture: Mitigation and adaptation potential of sustainable farming systems, FAO, Rome, Italy, 2009.

[28] Müller-Wenk R., Brandão M., Climatic impact of land use in LCA - carbon transfers between vegetation/soil and air, Int. J. Life Cycle Assess. 15 (2010) 172-182.

[29] Crews T.E., Peoples M.B., Legume versus fertilizer sources of nitrogen: ecological tradeoffs and human needs, Agric. Ecosyst. Environ. 102 (2004) 279-297.

[30] Gellings C.W., Parmenter K.E., Energy efficiency in fertilizer production and use, in: Gellings C.W., Blok K. (Eds.), Efficient use and conservation of energy, Encyclopedia of life support systems (EOLSS), Eolss Publ., Oxf., U.K., 2004.

[31] Stout B.A., Handbook of energy for world agriculture, Elsevier Appl. Sci., Lond., U.K., 1990.

[32] Pimentel D., Handbook of energy utilization in agriculture, CRC Press, Boca Raton, U.S.A., 1980.

[33] Bouwman A.F., Compilation of a global inventory of emissions of nitrous oxide, Univ. Wagening., Thesis, Wagening., Neth., 1995, $143 \mathrm{p}$. 


\section{Uso de recursos y emisiones de ocho especies de frutas cultivadas en Colombia.}

Resumen - Introducción. En muchos países tropicales el cultivo de frutas de alto valor es una actividad agrícola rentable, sin embargo cultivar frutas de forma intensiva requiere altas cantidades de insumos externos. El objetivo de este estudio fue cuantificar y comparar el uso de insumos (fertilizantes y pesticidas) durante el ciclo del cultivo de ocho especies de frutas tropicales comúnmente cultivadas en Colombia (Rubus glaucus, Solanum quitoense, Passiflora edulis, Cyphomandra betacea, Physalis peruviana, Ananas comosus, Persea americana, Mangifera indica). Adicionalmente se estimaron las emisiones de gases de efecto invernadero (GEI) en los sistemas de producción seleccionados, y se resalta el potencial de contribución de estos sistemas a la mitigación del cambio climático. Material y métodos. El análisis se basó sobre registros de estadísticas agropecuarias nacionales y se aplicó el enfoque de análisis de ciclo de vida considerando el uso de energía y emisiones de GEI como categorías de impacto. Adicionalmente se tomaron en cuenta algunos indicadores económicos con el propósito de integrar metas económicas con metas ambientales en los sistemas de producción. Resultados y discusión. Entre las ocho especies de frutas estudiadas, el manejo agronómico del mango (Mangifera indica) resultó en menos emisiones, mientras que el manejo del tomate de árbol (Cyphomandra betacea) fue el de mayor emisiones. Durante el estudio, se encontró para una misma especie una alta variabilidad en el uso de insumos entre los productores, indicando la necesidad de mejorar el manejo del cultivo a nivel de finca. El uso de fertilizantes inorgánicos fue la mayor fuente de emisiones de GEI. Alternativas para el manejo eficiente de energía y GEI tienen un alto potencial de reducir la huella de carbono del cultivo de frutas.

Colombia / frutales / frutas tropicales / cultivo / gases de efecto invernadero / análisis del ciclo de duración / consumo de energía / ordenación de recursos / agricultura sostenible 